\title{
In Vitro Screening for Antioxidant and Anticholinesterase Effects of Uvaria littoralis Blume.: A Nootropic Phytotherapeutic Remedy
}

\author{
Abdur Rahman ${ }^{1}$, Anamul Haque ${ }^{2}$, Md. Sahab Uddin ${ }^{1, *}$, Md. Mohsin Mian ${ }^{1}$, Mohammad Abu \\ Sufian ${ }^{1}$, Md. Mosiqur Rahman ${ }^{1}$, Yusuf Ali ${ }^{1}$, Md. Rajdoula Rafe ${ }^{1}$, Mohamed M. Abdel-Daim ${ }^{3}$, \\ Md. Josim Uddin ${ }^{4}$ and Md. Asaduzzaman ${ }^{1}$ \\ ${ }^{1}$ Department of Pharmacy, Southeast University, Dhaka, Bangladesh \\ ${ }^{2}$ Department of Pharmacy, Comilla University, Comilla, Bangladesh \\ ${ }^{3}$ Pharmacology Department, Faculty of Veterinary Medicine, Suez Canal University, Ismailia, Egypt \\ ${ }^{4}$ Department of Pharmacy, International Islamic University Chittagong, Chittagong, Bangladesh
}

\begin{abstract}
Background: Oxidative stress is strongly linked in the development of numerous chronic and degenerative disorders. Medicinal plants with antioxidant and anticholinesterase activities exert a key role for the management of oxidative stress related disorders mainly Alzheimer's disease (AD). Therefore the purpose of this study was to assess antioxidant potentiality and anticholinesterase inhibitory activity of crude methanolic extract (CME), petroleum ether fraction (PEF), chloroform fraction (CLF), ethyl acetate fraction (EAF) and aqueous fraction (AQF) of Uvaria littoralis (U. littoralis) leaves.

Methods: The antioxidant compounds namely total flavonoids contents (TFCs) and total proanthocyanidins contents (TPACCs) were determined for quantities constituent's characterization. Antioxidant capacity of $U$. littoralis leaves were estimated by the iron reducing power (IRPA), 1, 1-diphenyl-2-picrylhydrazyl (DPPH) radical scavenging and nitric oxide (NO) radical scavenging capacity. Anticholinesterase effects were estimated for acetylcholinesterase (AChE) and butyrylcholinestrase (BChE) activity.

Results: The EAF of $U$. littoralis leaves showed the highest TFCs as compared to CLF, CME, PEF and AQF. TPACCs were also found highest in EAF. The highest absorbance for IRPA was found in EAF $(2.220 \mathrm{~nm})$ with respect to CME and other fractions at the highest concentration. The EAF showed best DPPH and NO radical scavenging activity with $I_{50}$ values of 31.63 and $55.47 \mu \mathrm{g} / \mathrm{mL}$, respectively with regard to CME and remaining fractions. The PEF represents highest AChE inhibitory activity with $\mathrm{IC}_{50}$ values of $35.19 \mu \mathrm{g} / \mathrm{mL}$ and CLF showed highest BChE inhibitory activity with $I_{50}$ values of $32.49 \mu \mathrm{g} / \mathrm{mL}$.

Conclusions: The findings of the current study demonstrate the presence of antioxidant phytochemicals, likewise, turns out antioxidant and anticholinesterase potentiality of $U$. littoralis leaves which could be a prestigious candidate for the treatment of neurodegenerative diseases especially AD.
\end{abstract}

Keywords: Oxidative stress, Antioxidant potentiality, Anticholinesterase activity, Uvaria littoralis, Alzheimer's disease.

\section{INTRODUCTION}

Oxidative stress (OS) is an imbalance between prooxidant/antioxidant homeostasis that block the biological system's ability to readily mask the reactive intermediate oxygen species or to repair the resulting damage [1]. Toxic effects are produced from any inconveniences in the normal redox state of cells through the production of peroxides and free radicals that damage cell components, including proteins, lipids and deoxyribonucleic acid (DNA). Production of reactive oxygen species (ROS) is a particularly a slaughters situation in a biological system which is created by the OS such species include free radicals and peroxides. Hydroxyl $\left(\mathrm{OH}^{\circ}\right)$, superoxide $\left(\mathrm{O}^{2-*}\right)$ and nitric monoxide $\left(\mathrm{NO}^{\circ}\right)$ radicals are the most common

*Address correspondence to this author at the Department of Pharmacy, Southeast University, Dhaka, Bangladesh; Tel: +880 1710220110, 1670760546; E-mail: msu-neuropharma@hotmail.com,

msu_neuropharma@hotmail.com cellular free radicals. Likely hydrogen peroxide $\left(\mathrm{H}_{2} \mathrm{O}_{2}\right)$ and peroxynitrite $\left(\mathrm{ONOO}^{-}\right)$are also referred dangerous [2-5]. There is sufficient scientific evidence that proves that oxidative stress is most common causative agents for neurodegenerative diseases, mainly Alzheimer's disease (AD) [6]. Cellular changes show that OS is an event that precedes the appearance of the pathological hallmark of the $A D$ such as neurofibrillary tangles and senile plaques. The increased level of oxidative stress in the $A D$ brain is reflected by increased protein and DNA oxidation, enhanced lipid peroxidation, decreased level of cytochrome c oxidase and advanced glycosylation end products $[7,8]$. Ion imbalance and impaired metabolism caused by the weaken cell membrane which may produce from lipid peroxidation is also causative. Moreover oxidative stress can impair DNA methylation process which regulates gene expression. Amyloid- $\beta(A \beta)$ proteins may play a major role in pathogenesis of $A D$ and the trigger for $O S$ is an active area of current research [9]. 
Still $A D$ is incurable threat, but Alzheimer's medications can temporarily slow the worsening of symptoms and improve condition of patients [10]. Acetylcholinesterase (AChE) inhibitors and $\mathrm{N}$-methyl$\mathrm{D}$-aspartate glutamate receptor antagonists are the current standard therapy. Though these moderately improve quality of life, but it lacks a proper way of treatment [11]. Antioxidants are effective for breaking free radical chain reaction. Recently they emerged a great interest in the therapeutic potential of medicinal plants as antioxidants in reducing oxidative stressinduced tissue injury [12]. Ascorbic acid, carotenoids and phenolic compounds are more effective among the numerous naturally occurring antioxidants [13]. Although there is the availability of several synthetic antioxidants in a commercial manner, such as butylated hydroxyanisole (BHA) and butylated hydroxytoluene (BHT), but they are quite unsafe and their toxicity becomes a higher degree of concern [14]. Therefore, strong restrictions have been put forward on their application and there lays a trend to substitute them with naturally occurring antioxidants [14].

The plant, Uvaria littoralis (U. littoralis) Blume. belongs to the family Annonaceae is a woody climbing shrub [15]. Annonaceae comprises about 130 genera and 2,300 species [16]. Phytogeographically it is entirely tropical, with 39 genera being represented in tropical America. This plant family is recognized as being the center for isoquinoline alkaloids production in plants [16]. Among them several genera produce edible fruit. In folk medicines, their barks, leaves and roots of some plants of this family are used. Chemical compounds like flavonoids, alkaloids and acetogenins are extracted from the seeds and many other plants of this family. Flavonoids and alkaloids contained in the leaves and bark of several species of the family have shown insecticidal properties $[17,18]$.

There has been no study about antioxidant and anticholinesterase effects of the $U$. littoralis leaves. Therefore, the main objective of the present study was to evaluate the in vitro antioxidant and cholinesterase inhibitory activities of petroleum ether fraction (PEF), chloroform fraction (CLF), ethyl acetate fraction (EAF), aqueous fraction (AQF) and crude methanol extract (CME) of $U$. littoralis leaves.

\section{MATERIALS AND METHODS}

\section{Chemicals and Drugs}

Aluminium chloride $\left(\mathrm{AlCl}_{3}\right)$, ferrozine monosodium, DPPH (1, 1-diphenyl-2-picrylhydrazyl), Griess reagent, acetylthiocholine iodide, thiobarbituric acid and donepezil (Don) were purchased from Sigma-Aldrich, Japan. Butylated hydroxy toluene (BHT) was purchased from Merck, Germany. Gallic acid (GA) and quercetin were purchased from Wako pure chemicals Ltd., Japan. Unless otherwise specified, other chemicals were analytical grade and obtained from native sources.

\section{Collection, Identification, Drying and Grinding of Plant Materials}

The leaves of the plant, $U$. littoralis was collected during the month of October, 2016 from Comilla Hill track, Bangladesh in fresh condition and identified by an expert taxonomist. A voucher specimen was submitted to the National Herbarium Bangladesh (accession number: DACB-41884). In order to remove dirt, the leaves were cleaned with water, then the leaves were allowed to sun dried and then milled to generate powdered sample using a suitable grinder. The found milled powdered plant materials were reserved in an airtight glass conation awaiting extraction.

\section{Extraction and Fractionation of Plant Materials}

About $500 \mathrm{~g}$ dried leaf powder of $U$. littoralis was taken in an amber-colored glass bottle and soaked in 2 $\mathrm{L}$ methanol. The bottle was sealed for 10 days and shaken occasionally and stirred. The mixture was filtered by cotton and then by Whatman No.1 filter paper and finally filtrate was concentrated with a rotary evaporator at $52^{\circ} \mathrm{C}$ to find the crude methanol extract (CME, $45.39 \mathrm{~g}$ ). About $20 \mathrm{~g}$ of CME was taken in a separating funnel and fractionated using modified Kupchan method [13]. After fractionation petroleum ether (PEF, $5.89 \mathrm{~g}$ ), chloroform (CLF, $4.36 \mathrm{~g}$ ), ethyl acetate (EAF, $2.86 \mathrm{~g}$ ) and aqueous (AQF, $4.36 \mathrm{~g}$ ) soluble fractions were obtained and used for the experiment purpose.

\section{Estimation of Antioxidant Compounds}

The antioxidant compounds ware assayed for total flavonoid contents (TFCs) and total proanthocyanidin contents (TPACCs). A stock solution of $1 \mathrm{mg} / \mathrm{mL}$ was prepared for the CME and fractions just before the assay.

\section{Total Flavonoid Contents}

The method of Ordonez et al., was used for determining the TFCs [19]. A volume of $0.5 \mathrm{~mL}$ of $2 \%$ 
$\mathrm{AlCl}_{3}$ ethanol solution was added to $0.5 \mathrm{~mL}$ of plant extract/fractions solution. The mixture was incubated for $1 \mathrm{~h}$ at room temperature to complete the reaction. The absorbance was measured at $420 \mathrm{~nm}$ in contrast to a reagent blank. The TFCs were calculated by $\mathrm{mg}$ of quercetin equivalent (QRE) per $g$ of dried sample.

\section{Total Proanthocyanidin Contents}

The method described by Sun et al., was used to determine the content of TPACCs [20]. A volume of 0.5 $\mathrm{mL}$ of plant extract/fractions solution was mixed with 3 $\mathrm{mL}$ of $4 \%$ vanillin-methanol solution and $1.5 \mathrm{~mL}$ hydrochloric acid. After that the mixture was allowed to stand for $15 \mathrm{~min}$ at room temperature. The absorbance was measured at $500 \mathrm{~nm}$ in contrast to a reagent blank. The TPACCs were expressed in terms of $\mathrm{mg}$ of catechin equivalent (CTE) per $\mathrm{g}$ of dried sample.

\section{Estimation of Antioxidant Activity}

The antioxidant capacity was assayed for the iron reducing power activity (IRPA), DPPH radical scavenging and nitric oxide (NO) radical scavenging capacity. A stock solution of $1 \mathrm{mg} / \mathrm{mL}$ was prepared for the CME and fractions just before the assay.

\section{Iron Reducing Power Activity}

The method of Oyaizu was used to determine the iron reducing power activity [21]. A volume of $0.2 \mathrm{~mL}$ of plant extract/fractions solution was mixed with $0.5 \mathrm{~mL}$ of $200 \mathrm{mM} / \mathrm{L}$ trisodium phosphate buffer ( $\mathrm{pH} \mathrm{6.6)}$ and $2.5 \mathrm{~mL}$ of $1 \%$ potassium ferricyanide. The mixture was incubated at $50{ }^{\circ} \mathrm{C}$ for $20 \mathrm{~min}$; then, $2.5 \mathrm{~mL}$ of $10 \%$ trichloroacetic acid (w/v) was added and the mixture was centrifuged at $650 \mathrm{rpm}$ for $10 \mathrm{~min} .0 .5 \mathrm{~mL}$ supernatant solution was mixed with $0.5 \mathrm{~mL}$ deionized water and $0.1 \mathrm{~mL}$ of $0.1 \%$ ferric chloride and absorbance was measured at $700 \mathrm{~nm}$ in contrast to a reagent blank. In this test ascorbic acid (AA) was used as standard.

\section{DPPH Radical Scavenging Activity}

The method of Choi et al., was used for determination of DPPH radical scavenging activity [22]. A volume of $2 \mathrm{~mL}$ of methanol solution of plant extract/fractions or standard at various concentrations and $3 \mathrm{~mL}(0.02 \%)$ of methanol solution of DPPH was added then incubated at room temperature for $30 \mathrm{~min}$ in dark. The absorbance of the solution was measured at $517 \mathrm{~nm}$ in contrast to a reagent blank. In this test $\mathrm{BHT}$ was used as standard. The percentage inhibitions or scavenging of DPPH radical was calculated by using the following formula:

DPPH radical scavenging $(\%)=\left[\left(A_{\circ}-A_{1}\right) / A_{o}\right] \times 100$

where, $A_{0}$ is the absorbance of the control and $A_{1}$ is the absorbance of the sample/standard.

\section{Nitric Oxide Radical Scavenging Activity}

The method of Garrat was used to determine the nitric oxide radical scavenging activity [23]. A volume of $2 \mathrm{~mL}$ of $10 \mathrm{mM}$ sodium nitroprusside in $0.5 \mathrm{~mL}$ phosphate buffer saline $(\mathrm{pH} 7.4)$ was mixed with 0.5 $\mathrm{mL}$ of plant extract/fractions or standard at various concentrations and the mixture was incubated at $25^{\circ} \mathrm{C}$ for $2.5 \mathrm{~h}$. An aliquot of $0.5 \mathrm{~mL}$ of the solution was added to $0.5 \mathrm{~mL}$ of Griess reagents [1.0 mL of sulfanilic acid reagent $(0.33 \%$ prepared in $20 \%$ glacial acetic acid at room temperature for 5 min with $1.0 \mathrm{~mL}$ of naphthyethylenediamine chloride $(0.1 \% \mathrm{w} / \mathrm{v})]$. The mixture was incubated at room temperature for $30 \mathrm{~min}$. The absorbance was then measured at $540 \mathrm{~nm}$ in contrast to a reagent blank. In this test GA was used as standard. The percentage inhibitions or scavenging of NO radical was calculated by using the following formula:

NO radical scavenging $(\%)=\left[\left(A_{o}-A_{1}\right) / A_{0}\right] \times 100$

where, $A_{o}$ is the absorbance of the control and $A_{1}$ is the absorbance of the sample/standard.

\section{Estimation of Cholinesterase Inhibitory Activity}

The acetylcholinesterase (AChE) and butyrylcholinestrase (BChE) inhibitory activity were carried out by the use of bovine brain homogenate as acetylcholinesterase enzyme source and human blood as butyrylcholinestrase enzyme source. A stock solution of $1 \mathrm{mg} / \mathrm{mL}$ was prepared for the CME and fractions just before the assay.

\section{Acetylcholinesterase Inhibitory Activity}

The method of Ellman et al., with slight modification was used to determine the AChE inhibitory activity using acetylthiocholine iodide as a substrate [24]. Bovine brain was used as enzyme source and homogenized with 5 volumes of a homogenation buffer [50 mM Tris- $\mathrm{HCl}(\mathrm{pH} 7.2)$, contained $1 \mathrm{M} \mathrm{NaCl}, 50 \mathrm{mM}$ magnesium chloride and $1 \%$ Triton $\mathrm{X}-100]$ and centrifuged at $10,000 \mathrm{rpm}$ for $15 \mathrm{~min}$. The resulting supernatant was used as an enzyme source. All of the extraction steps were carried out at $4^{\circ} \mathrm{C}$. Each plant 
extract/fractions or standard solution $(500 \mu \mathrm{l})$ was mixed with an enzyme solution $(200 \mu \mathrm{l})$ and incubated at $37^{\circ} \mathrm{C}$ for $15 \mathrm{~min}$ and absorbance was read at 405 $\mathrm{nm}$ immediately after adding an Ellman's reaction mixture [3.5 mL of $0.5 \mathrm{mM}$ acetylthiocholine, $1 \mathrm{mM}$ of 5 , 5 '-dithio-bis (2-nitro benzoic acid)] in a $50 \mathrm{mM}$ sodium phosphate buffer $(\mathrm{pH} 8.0)$ to the above reaction mixture. The blank reaction was measured by substituting saline for the enzyme. In this test Don was used as standard. The percentage inhibition of AChE activity was calculated by using the following formula:

AChE Inhibition $(\%)=\left[\left(A_{\circ}-A_{1}\right) / A_{o}\right] \times 100$

where, $A_{0}$ is the absorbance of the control and $A_{1}$ is the absorbance of the sample/standard.

\section{Butyrylcholinestrase Inhibitory Activity}

The method of Ellman's et al., with slight modification was used for the determination of BChE inhibitory activity using S-butyrylthiocholine iodide as a substrate [24]. Human blood was used as enzyme source and homogenized in a homogenizer with 5 volumes of $3 \%$ sodium oxalate (anticoagulant) and centrifuged at $10,000 \mathrm{rpm}$ for $15 \mathrm{~min}$. The resulting supernatant was used as an enzyme source. All of the extraction steps were carried out at $4^{\circ} \mathrm{C}$. Each plant extract/fractions or standard solution $(500 \mu \mathrm{l})$ was mixed with an enzyme solution $(50 \mu \mathrm{l})$ and incubated at $37^{\circ} \mathrm{C}$ for $15 \mathrm{~min}$. Absorbance was measured at $405 \mathrm{~nm}$ immediately after adding an Ellman's reaction mixture [3.5 mL of $0.5 \mathrm{mM}$ S-butyrylthiocholine, $1 \mathrm{mM}$ of $5,5^{\prime}-$ dithio-bis (2-nitro benzoic acid)] in a $50 \mathrm{mM}$ sodium phosphate buffer $(\mathrm{pH} 8.0)$ to the above reaction mixture. The blank reaction was measured by substituting buffer instead of enzyme. In this test Don was used as standard. The percentage inhibition of BChE activity was calculated by using the following formula:

BChE Inhibition $(\%)=\left[\left(A_{o}-A_{1}\right) / A_{o}\right] \times 100$

where, $A_{o}$ is the absorbance of the control and $A_{1}$ is the absorbance of the sample/standard.

\section{Statistical Analysis}

The results obtained were represented as mean \pm SD from three separate interpretations. Student's t-test was used to find the concern of standard and sample for $I_{50}$ values. For the statistical and graphical estimations SPSS 14.0 (Chicago, IL, USA) and Microsoft Excel 2010 (Roselle, IL, USA) were used. The results were measured as statistically significant at the value of $P<0.05$.

\section{RESULTS}

\section{Determination of TFCs}

Quercetin standard curve $\left(y=0.0075 x+0.1504, R^{2}\right.$ $=0.9887)$ was used for the determination of TFCs. The TFCs of $U$. littoralis leaf extract and its fraction ranges from 61.58 (AQF) to 215.06 (EAF) $\mathrm{mg} Q R E / g$. The TFCs follow the following order: EAF > CLF > CME > PEF > AQF are specified in Figure 1.

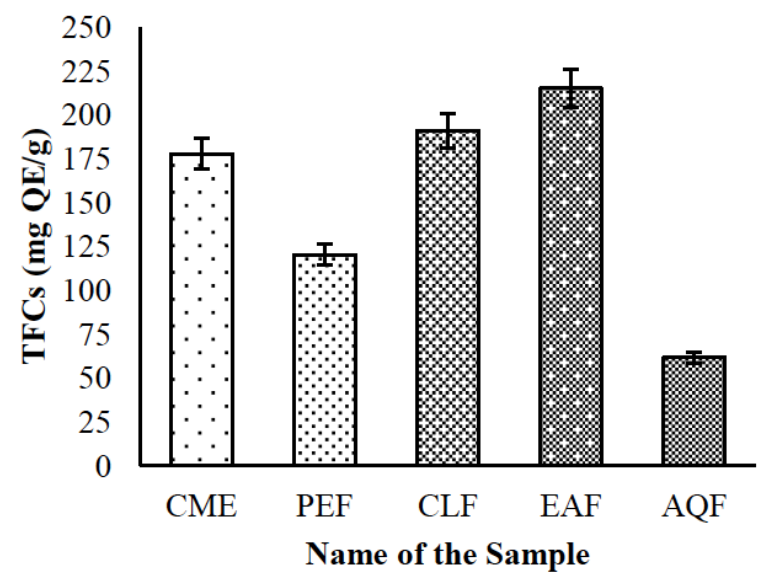

Figure 1: TFCs of $U$. littoralis leaf extract and fractions.

Values were reported as mean $\pm S D(n=3)$. CME $=$ Crude methanolic extract, $\mathrm{PEF}=$ Petroleum ether fraction, $\mathrm{CLF}=$ Chloroform fraction, $E A F=$ Ethyl acetate fraction, $A Q F=$ Aqueous fraction.

\section{Determination of TPACCs}

Catechin standard curve $\left(y=0.0019 x+0.2024, R^{2}\right.$ $=0.9723$ ) was used for determination of TPACCs. $U$. littoralis leaf extract and its fraction show a range of TPACCs from 22.03 (AQF) to 95.72 (EAF) mg CTE/g.

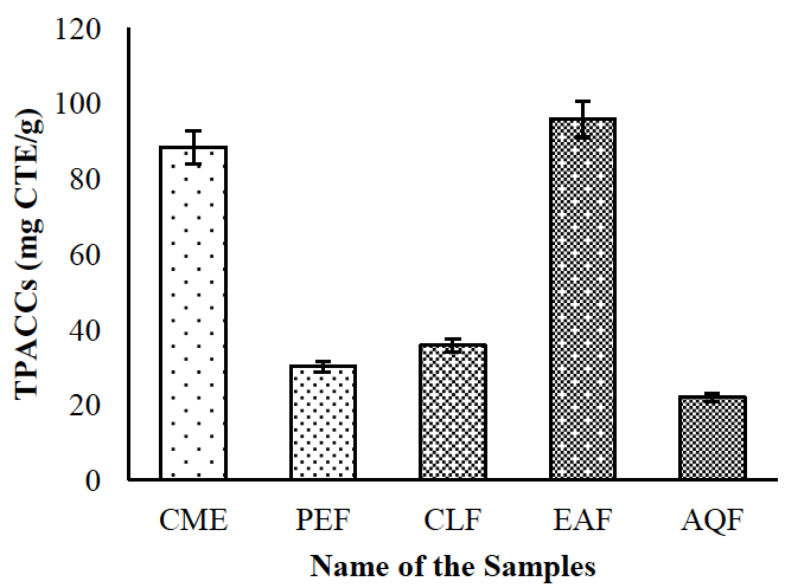

Figure 2: TPACCs of $U$. littoralis leaf extract and fractions.

Values were reported as mean $\pm S D(n=3)$. CME $=$ Crude methanolic extract, PEF = Petroleum ether fraction, $\mathrm{CLF}=$ Chloroform fraction, EAF = Ethyl acetate fraction, AQF = Aqueous fraction. 


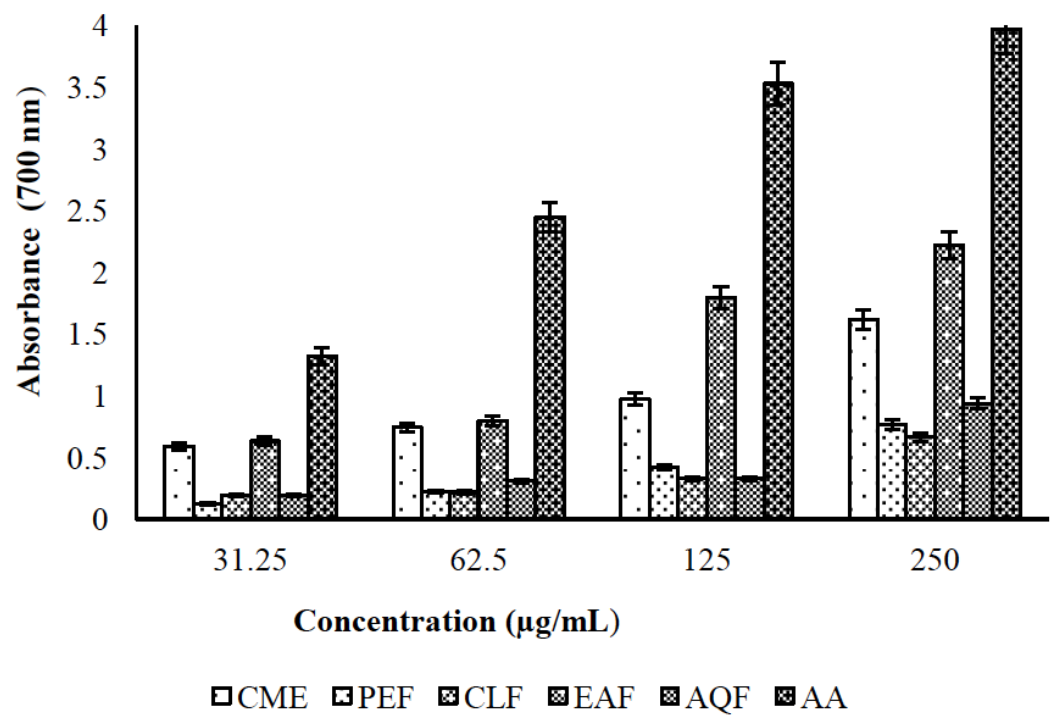

Figure 3: IRPA of $U$. littoralis leaf extract and fractions.

Values were reported as mean $\pm S D(n=3)$. CME $=$ Crude methanolic extract, PEF = Petroleum ether fraction, CLF $=$ Chloroform fraction, $E A F=$ Ethyl acetate fraction, $A Q F=$ Aqueous fraction, $A A=$ Ascorbic acid.

EAF shows highest content and follow the following order: $\mathrm{EAF}>\mathrm{CME}>\mathrm{CLF}>\mathrm{PEF}>\mathrm{AQF}$ (Figure 2).

\section{Determination of IRPA}

IRPA of the $U$. littoralis leaf extract and its fraction at different concentrations showed a dose dependent activity. The Figure 3, displayed the range of IRPA from 0.665 (CLF) to 2.220 (EAF) nm at $250 \mu \mathrm{g} / \mathrm{mL}$. Results displayed the following order of antioxidant activity: AA $>\mathrm{EAF}>\mathrm{CME}>\mathrm{AQF}>\mathrm{PEF}>\mathrm{CLF}$ at the highest concentration.

\section{Determination of DPPH Radical Scavenging Activity}

The DPPH scavenging effects of $U$. littoralis leaf extract/fractions and standard are specified in Figure 4,

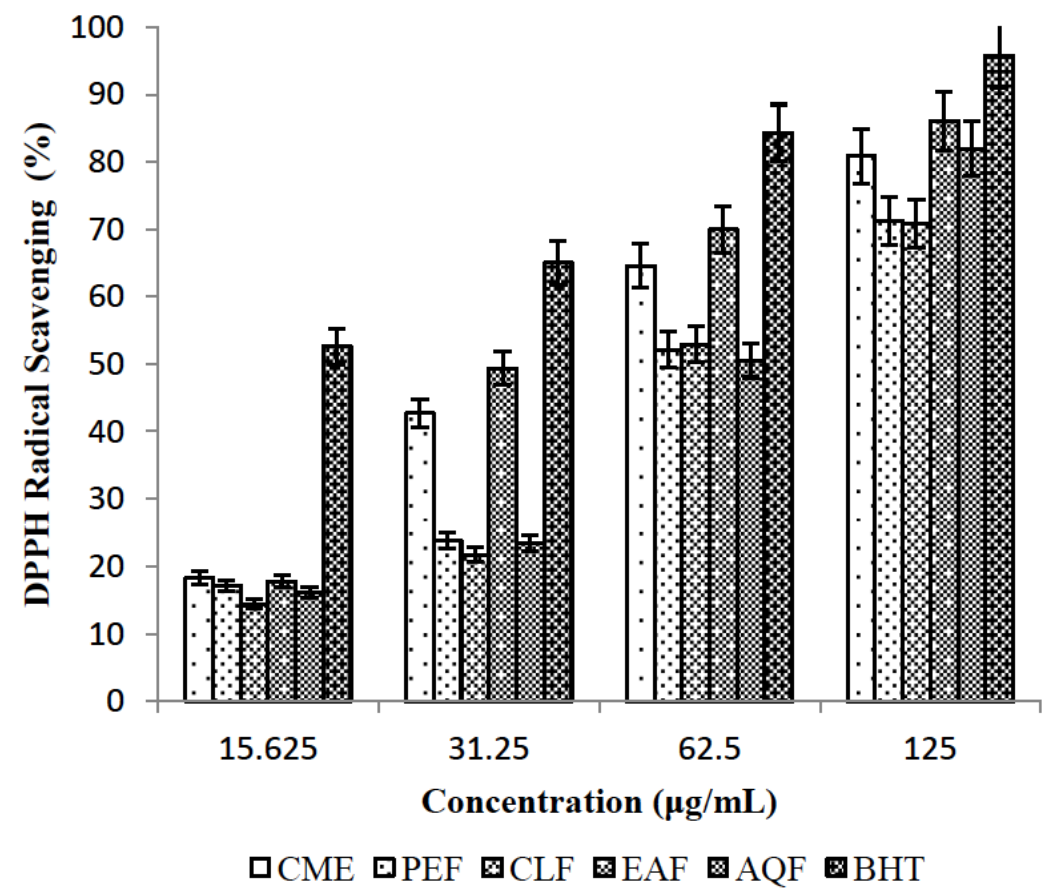

Figure 4: DPPH radical scavenging assay of $U$. littoralis leaf extract and fractions.

Values were reported as mean $\pm \mathrm{SD}(\mathrm{n}=3)$. $\mathrm{CME}=$ Crude methanolic extract, $\mathrm{PEF}=$ Petroleum ether fraction, $\mathrm{CLF}=$ Chloroform fraction, $\mathrm{EAF}=\mathrm{Ethyl}$ acetate fraction, $\mathrm{AQF}=$ Aqueous fraction, $\mathrm{BHT}=$ Butylated hydroxytoluene. 
in which the scavenging percentages follow the following order: $\mathrm{BHT}>\mathrm{EAF}>\mathrm{AQF}>\mathrm{CME}>\mathrm{PEF}>$ CLF at $125 \mu \mathrm{g} / \mathrm{mL}$. The established relationship between the percentage of DPPH radical scavenging and concentration was dose dependent. The $\mathrm{IC}_{50}$ values of CME, PEF, CLF EAF, AQF and BHT are depicted in Table 1.

Table 1: $\quad \mathrm{IC}_{50}$ Values of $U$. littoralis Leaf Extract and Fractions for DPPH and NO Radical Scavenging Activity

\begin{tabular}{|c|c|c|}
\hline \multirow{2}{*}{ Sample/Standard } & \multicolumn{2}{|c|}{ IC $_{50}$ Values $(\mu \mathrm{g} / \mathrm{mL})$} \\
\cline { 2 - 3 } & DPPH Radical & NO Radical \\
\hline \hline CME & $57.29 \pm 2.22$ & $146.46 \pm 0.755$ \\
\hline PEF & $59.89 \pm 1.26$ & $171.60 \pm 1.25$ \\
\hline CLF & $59.06 \pm 1.42$ & $132.57 \pm 1.77$ \\
\hline EAF & $31.63 \pm 0.834$ & $55.47 \pm 0.598$ \\
\hline AQF & $61.83 \pm 1.94$ & $115.22 \pm 0.642$ \\
\hline BHT & $14.86 \pm 0.169$ & - \\
\hline GA & - & $27.80 \pm 0.162$ \\
\hline
\end{tabular}

Values were reported as mean $\pm S D(n=3)$. CME $=$ Crude methanolic extract, $\mathrm{PEF}=$ Petroleum ether fraction, $\mathrm{CLF}=$ Chloroform fraction, $\mathrm{EAF}=$ Ethyl acetate fraction, $\mathrm{AQF}=$ Aqueous fraction, $\mathrm{BHT}=$ Butylated hydroxytoluene, $\mathrm{GA}$ $=$ Gallic acid. " $P<0.01$ significant difference from the standard.

\section{Determination of NO Radical Scavenging Activity}

Figure 5 displays the NO radical scavenging activity of $U$. littoralis leaf extract/fractions and standard in which the percentage of scavenging activity follows the following order: $\mathrm{GA}>\mathrm{EAF}>\mathrm{AQF}>\mathrm{CLF}>\mathrm{CME}>\mathrm{PEF}$ at $125 \mu \mathrm{g} / \mathrm{mL}$. The $\mathrm{IC}_{50}$ values of CME, PEF, CLF EAF, $A Q F$ and GA are shown in Table 1. Results expressed that the $\mathrm{IC}_{50}$ value of EAF was statistically significant $(P$ $<0.01$ ) with respect to $G A$.

\section{Determination of AChE Inhibitory Activity}

Figure 6, revealed that the AChE inhibitory activity of $U$. littoralis extract/fractions and standard in the following order: Don > PEF > CLF > EAF > CME > $A Q F$ at $125 \mu \mathrm{g} / \mathrm{mL}$. The $\mathrm{IC}_{50}$ values of Don, PEF, CLF, $\mathrm{EAF}, \mathrm{CME}$ and $\mathrm{AQF}$ were $16.793,35.19,38.51$, 135.97, 137.71 and $153.68 \mu \mathrm{g} / \mathrm{mL}$ are expressed in Table 2.

\section{Determination of BChE Inhibitory Activity}

The BChE inhibitory activity of $U$. littoralis extract/fractions and standard were in the following order: Don > CLF > EAF > CME > PEF > AQF at 125 $\mu \mathrm{g} / \mathrm{mL}$ are assumed in Figure 7 . The $I_{50}$ values of Don, CLF, EAF, CME, PEF and AQF were 16.71,

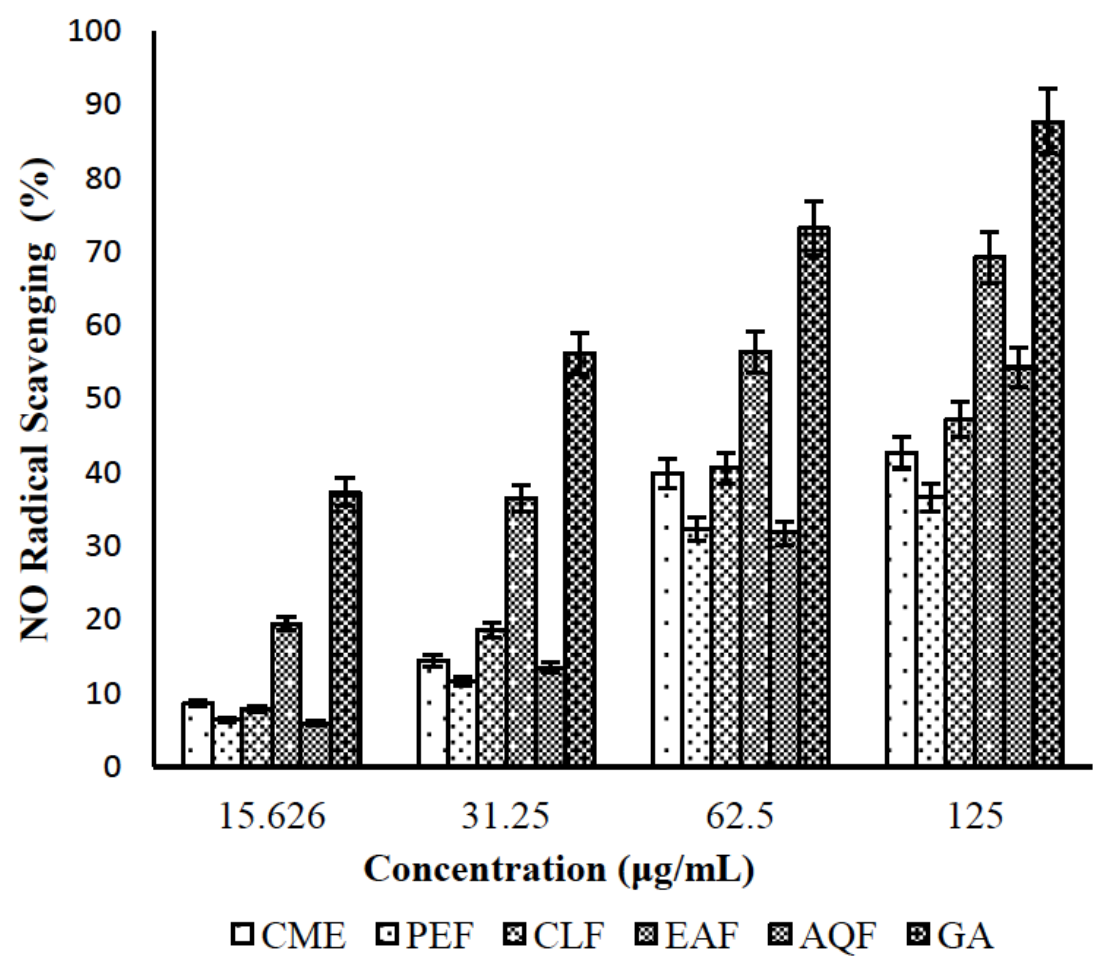

Figure 5: NO radical scavenging assay of $U$. littoralis leaf extract and fractions.

Values were reported as mean $\pm S D(n=3)$. CME = Crude methanolic extract, $P E F=$ Petroleum ether fraction, CLF = Chloroform fraction, EAF $=$ Ethyl acetate fraction, $A Q F=$ Aqueous fraction, $\mathrm{GA}=$ Gallic acid. 


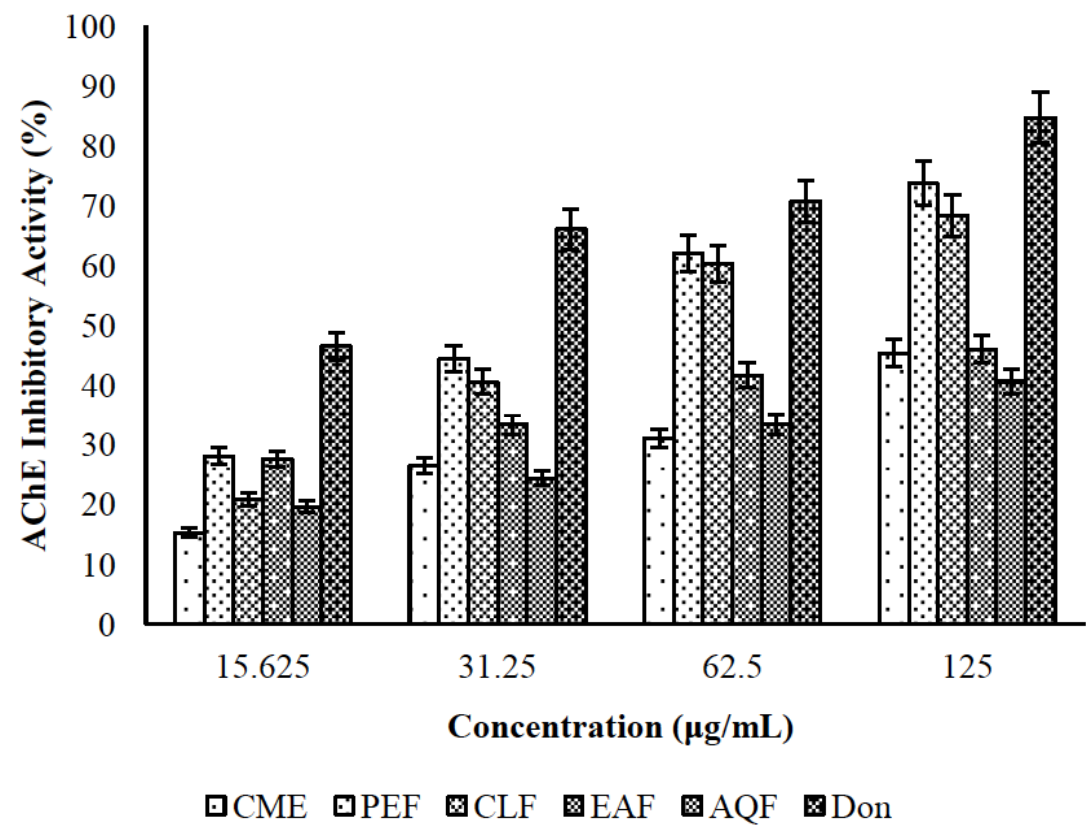

Figure 6: AChE inhibitory activity of $U$. littoralis leaf extract and fractions.

Values were reported as mean $\pm S D(n=3)$. CME $=$ Crude methanolic extract, PEF = Petroleum ether fraction, CLF $=$ Chloroform fraction, EAF = Ethyl acetate fraction, $\mathrm{AQF}=$ Aqueous fraction, Don $=$ Donepezil.

Table 2: $\quad I_{50}$ Values of $U$. littoralis Leaf Extract and Fractions for AChE and BChE Inhibitory Activity

\begin{tabular}{|c|c|c|}
\hline \multirow{2}{*}{ Sample/Standard } & \multicolumn{2}{|c|}{ IC $_{50}$ Values $(\boldsymbol{\mu g} / \mathrm{mL})$} \\
\cline { 2 - 3 } & AChE & BChE \\
\hline \hline CME & $137.71 \pm 6.32$ & $62.10 \pm 1.05$ \\
\hline PEF & $35.19 \pm 1.295$ & $58.11 \pm 1.48$ \\
\hline CLF & $38.51 \pm 1.32$ & $32.49 \pm 1.01$ \\
\hline EAF & $135.97 \pm 7.64$ & $34.89 \pm 1.22$ \\
\hline AQF & $153.68 \pm 3.73$ & $129.94 \pm 4.05$ \\
\hline Don & $16.793 \pm 0.2569$ & $16.71 \pm 0.208$ \\
\hline
\end{tabular}

Values were reported as mean $\pm \mathrm{SD}(\mathrm{n}=3)$. CME $=$ Crude methanolic extract, $\mathrm{PEF}=$ Petroleum ether fraction, $\mathrm{CLF}=\mathrm{Chloroform}$ fraction, $\mathrm{EAF}=\mathrm{Ethyl}$ acetate fraction, $A Q F=$ Aqueous fraction, Don $=$ Donepezil.

$32.49, \quad 34.89, \quad 62.10, \quad 58.11$ and $129.94 \mu \mathrm{g} / \mathrm{mL}$ presented in Table 2.

\section{DISCUSSION}

$A D$ is a chronic neurogenarative disorder leading to death among the elderly people [25, 26]. Various factors have been identified for pathogenesis of $A D$, oxidative stress and impairment in the function of cholinergic activity has been found the major contributing factors [27, 28]. It is well established evidence that the compounds obtained from plant having antioxidants and anticholinesterase activity spatially AChE and BChE inhibitory activity would be effective for the management of $A D[29,30]$. In this study antioxidant and anticholinesterase activities of the CME and its resulting fractions of $U$. littoralis leaves were tested.

Among the fractions the highest TFCs was found in EAF with respect to remaining. TPACCs consist of flavan-3-ol units including catechin, epicatechin, catechin gallate and epicatechin gallate. Inhibition of $A \beta$ aggregation is an important strategy for $A D$. Some flavonoids have been identified and active in the modulation of the pathological processes of $A D$ [31]. Like flavonoid among the plant extract/fractions the highest TPACCs was found in EAF. A number of studies recommended the potent role of phytoconstituents and proanthocyanadins rich natural compounds for the controlling of neurological disorders including AD [32]. 


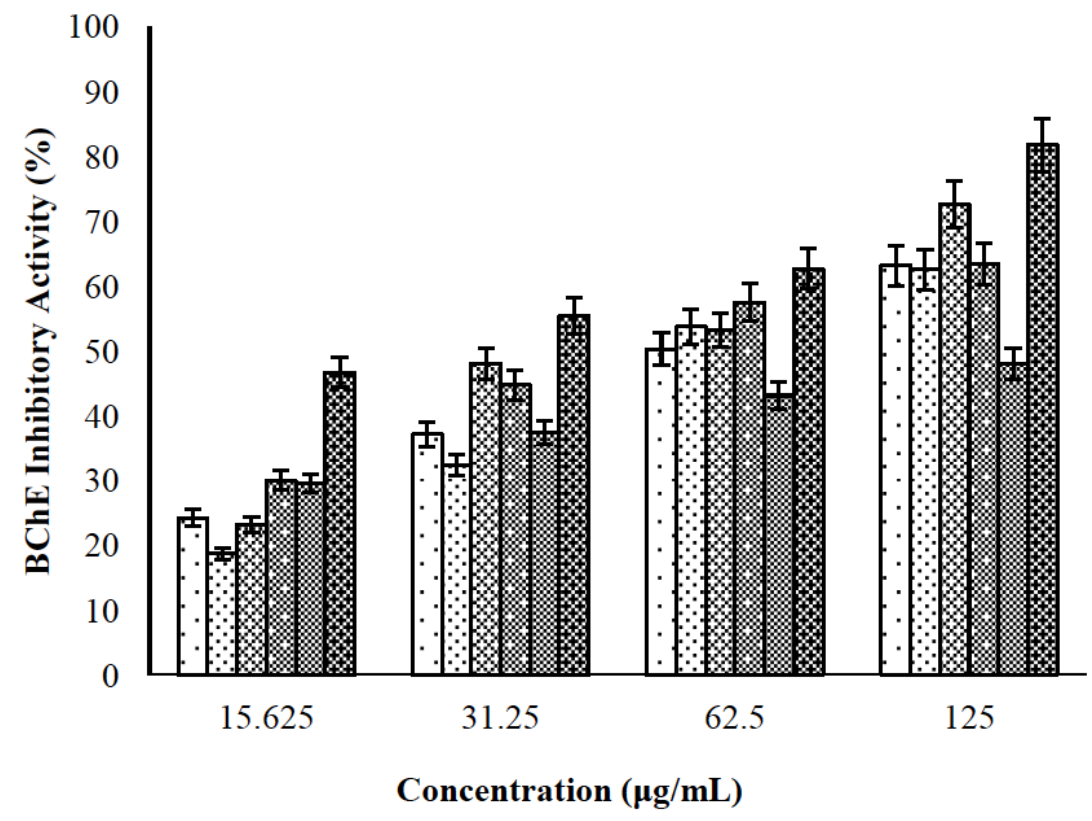

口CME $\square \mathrm{PEF} \quad \mathrm{CLF} \quad \mathrm{EAF} \quad \mathrm{AQF} \otimes \mathrm{Don}$

Figure 7: BChE inhibitory activity of $U$. littoralis leaf extract and fractions.

Values were reported as mean $\pm \mathrm{SD}(\mathrm{n}=3)$. CME $=$ Crude methanolic extract, $\mathrm{PEF}=$ Petroleum ether fraction, CLF $=$ Chloroform fraction, EAF = Ethyl acetate fraction, $\mathrm{AQF}=$ Aqueous fraction, Don $=$ Donepezil.

Antioxidant decreases free-radical-mediated damage in neuronal cells and help to inhibit dementia in mammalian brain cells [33]. Medicinal plant with reducing power donates an electron might be stabilized free radicals and inhibits the radical chain reactions [34]. Among CME and the four different fractions, EAF showed the highest IRPA with absorbance of $2.220 \mathrm{~nm}$ at highest concentration. Free radicals are linked to numerous diseases and there are strong reasons to believe that the free radical as a pathogenic factor for $A D$ as stated earlier might be due to its toxicity and its role in various reactions such as Fenton's, involving iron [35]. In this study for the DPPH scavenging activity, EAF showed the highest scavenging. The highest percentage of $\mathrm{NO}$ radical scavenging activity was also reported for EAF. The study suggested that metals play a foremost catalytic role in the formation of free radicals and attention has centered on the role of many metals in $A D[6]$.

Only symptomatic treatment proven for $A D$ is the use of cholinesterase (ChE) inhibitors [36]. In case of healthy brain, AChE dominates (i.e., 80\%) and butyrylcholinesterase (BChE) is considered to show a minor role in controlling brain acetylcholine (ACh) levels [37]. In the AD brain, BChE activity rises, whereas AChE activity remains constant or declines $[37,38]$. In fact, both enzymes are likely to have connection in controlling $\mathrm{ACh}$ levels and exert potent therapeutic targets to upgrade the cholinergic deficit [37]. Recent study showed that BChE may also have a role in the etiology and progression of $A D$ by regulation of synaptic AChE levels [39, 40]. Therefore, specific AChE and BChE inhibitors development can improve clinical outcomes of AD patients [40]. In this study the highest AChE inhibitory activity was found in PEF and the highest BChE activity was found in CLF. Inhibition of $\mathrm{AChE}$ and BChE is suggested as the foremost therapeutic strategy against AD [41]. Several studies suggested that nootropic medicinal plants are effective for controlling Alzheimer's pathogenesis by regulating ChE $[3,42]$

\section{CONCLUSION}

The results acquired from the current study establish that EAF of $U$. littoralis leaves showed the highest antioxidant activity while PEF and CLF showed the highest anticholinesterase inhibitory activity with respect to remaining extract and fractions. Consequently $U$. littoralis leaves could be used as natural antioxidants, alternative anticholinesterase drugs and effective to treat various cognitive and neurodegenerative disorders, particularly $A D$. Nevertheless, further studies are needed to isolate and identify responsible nootropic compound(s). 


\section{ABBREVIATIONS}

Uvaria littoralis $=U$. littoralis

$\mathrm{AD} \quad=$ Alzheimer's disease

OS

DNA = Deoxyribonucleic acid

ROS $\quad=$ Reactive oxygen species

$\mathrm{OH}^{\circ} \quad=$ Hydroxyl radical

$\mathrm{O}^{2-\cdot} \quad=$ Superoxide radical

$\mathrm{NO}^{\circ} \quad=$ Nitric monoxide radical

NO $\quad=$ Nitric oxide

$\mathrm{H}_{2} \mathrm{O}_{2} \quad=$ Hydrogen peroxide

$\mathrm{ONOO}^{-}=$Peroxynitrite

$A \beta=$ Amyloid $-\beta$

BHA = Butylated hydroxyanisole

BHT= = Butylated hydroxytoluene

$\mathrm{AlCl}_{3} \quad=$ Aluminium chloride

DPPH $\quad=1,1$-diphenyl-2-picrylhydrazyl

Don = Donepezil

GA = Gallic acid

QRE = Quercetin equivalent

CTE = Catechin equivalent

CME = Crude methanolic extract

PEF = Petroleum ether fraction

CLF $=$ Chloroform fraction

EAF = Ethyl acetate fraction

AQF $=$ Aqueous fraction

AA $=$ Ascorbic acid

TFCs = Total flavonoids contents

TPACCs = Total proanthocyanidins contents

IRPA $=$ Iron reducing power

$\begin{array}{ll}\mathrm{AChE} & =\text { Acetylcholinesterase } \\ \mathrm{BChE} & =\text { Butyrylcholinestrase } \\ \mathrm{ChE} & =\text { Cholinesterase } \\ \mathrm{ACh} & =\text { Acetylcholine }\end{array}$

AUTHORS' CONTRIBUTIONS

This work was carried out in collaboration between all authors. Authors MSU and MA designed the study, wrote the protocol and managed the analyses of the study. Author AH provided the plant sample. Authors $A R, M S U, M M M$, and MAS performed the laboratory experiments and prepared the manuscript. Authors MMR, YA, MRR, MMAD and MJU reviewed the scientific content of the manuscript. All the authors read and approved the final manuscript.

\section{ACKNOWLEDGEMENTS}

The authors wish to thank the anonymous reviewer(s)/editor(s) of this article for their constructive reviews. The authors wish to thank the Department of Pharmacy, Southeast University, Dhaka, Bangladesh for providing support in conducting this research.

\section{ETHICAL APPROVAL}

The study protocol was approved by the ethics committee of the Department of Pharmacy, Southeast University, Dhaka, Bangladesh. The study was conducted in accordance with the ethical standards laid down in the 1964 Declaration of Helsinki.

\section{COMPETING INTERESTS}

The authors proclaim that they have no competing interests.

\section{REFERENCES}

[1] Uddin MS, Mamun AA, Khanum S, Begum Y, Alam MS. Analysis of in vitro antioxidant activity of Caryota urens L. leaves: A traditional natural remedy. J Coast Life Med 2016; 4: 483-9. https://doi.org/10.12980/jclm.4.2016J6-65

[2] Uddin MS, Nasrullah M, Hossain MS, Rahman MM, Sarwar MS, Amran MS, el al. Evaluation of nootropic activity of Persicaria flaccida on cognitive performance, brain antioxidant markers and acetylcholinesterase activity in rats: Implication for the management of Alzheimer's disease. American J Psychi Neuroscience 2016; 4(2): 26-37. https://doi.org/10.11648/j.ajpn.20160402.12

[3] Uddin MS, Mamun AA, Hossain MS, Akter F, Iqbal MA, Asaduzzaman M. Exploring the effect of Phyllanthus emblica L. on cognitive performance, brain antioxidant markers and acetylcholinesterase activity in rats: Promising natural gift for 
the mitigation of Alzheimer's disease. Ann Neurosci 2016; 23(4): 218-229.

https://doi.org/10.1159/000449482

[4] Uddin MS, Al Mamun A, Hossain MS, Ashaduzzaman M, Noor MA, Hossain MS, Uddin MJ, Sarker J, Asaduzzaman M. Neuroprotective effect of Phyllanthus acidus L. on learning and memory impairment in a scopolamine-induced animal model of dementia and oxidative stress: Natural wonder for regulating the development and progression of Alzheimer's disease. Adv Alzheimer Dis 2016; 5(2): 53-72. http://dx.doi.org/10.4236/aad.2016.52005

[5] Hybertson BM, Gao B, Bose SK, McCord JM. Oxidative stress in health and disease: The therapeutic potential of Nrf2 activation. Molecular Asp Medicine 2011; 32(4): 234-46.

[6] Uddin MS, Haque A, Mamun AA, Iqbal MA, Kabir MT. Searching the linkage between high fat diet and Alzheimer's disease: A debatable proof stand for ketogenic diet to alleviate symptoms of Alzheimer's patient with APOE $\varepsilon 4$ allele. J Neurol Neurophysiol 2016; 7(5): 1-2. http://dx.doi.org/10.4172/2155-9562.1000397

[7] Jomova K, Vondrakova D, Lawson M, Valko M. Metals, oxidative stress and neurodegenerative disorders. Mol Cel Bioch 2010; 345(1-2): 91-104.

[8] Zhang M, Schmitt-Ulms G, Sato C, Xi Z, Zhang Y, Zhou Y, St George-Hyslop P, Rogaeva E. Drug repositioning for Alzheimer's disease based on systematic 'omics' data mining. PloS one 2016; 11(12): e0168812.

[9] Uddin MS, Asaduzzaman M, Mamun AA, Iqbal MA, Wahid F. Neuroprotective activity of Asparagus racemosus Linn. against ethanol-induced cognitive impairment and oxidative stress in rats brain: Auspicious for controlling the risk of Alzheimer's disease. J Alzheimers Dis Parkinsonism 2016; 6(4): 1-2. http://dx.doi.org/10.4172/2161-0460.1000245

[10] Forchetti CM. Treating patients with moderate to severe Alzheimer's disease: Implications of recent pharmacologic studies. Prim Care Companion J Clin Psychiatry 2015; 7(4): 155-161.

[11] Čolović MB, Krstić DZ, Lazarević-Pašti TD, Bondžić AM, Vasić VM. Acetylcholinesterase inhibitors: Pharmacology and toxicology. Cur Neuropharma 2013; 11(3): 315-335.

[12] Kurutas EB. The importance of antioxidants which play the role in cellular response against oxidative/nitrosative stress: Current state. Nutrition J 2015; 15: 71.

[13] Das N, Islam ME, Jahan N, et al. Antioxidant activities of ethanol extracts and fractions of Crescentia cujete leaves and stem bark and the involvement of phenolic compounds. BMC Comp Alt Med 2014; 14: 45.

[14] Kahl R, Kappus $H$. Toxicology of the synthetic antioxidants $\mathrm{BHA}$ and $\mathrm{BHT}$ in comparison with the natural antioxidant vitamin E. Z Lebensm Unters Forsch 1993; 196(4): 329-38.

[15] Kessler PJ, Bos MM, Daza SS, Kop A, Willemse LP, Pitopang R, Gradstein SR. Checklist of woody plants of Sulawesi, Indonesia. Blumea. Supplement 2002; 14(1): 1-60. http://floramalesiana.org/doc/kessler2002_sulawesi.pdf

[16] da Silva Almeida JR, Lúcio AS, Barbosa-Filho JM, de Fátima Agra M, da Silva MS, da Cunha EV, et al., Alkaloids and a new cinnamate derivative from Duguetia gardneriana. Biochemical Sys Eco 2007; 35(7): 456-8.

[17] Pardhasaradhi BV, Reddy M, Ali AM, Kumari AL, Khar A. Differential cytotoxic effects of Annona squamosa seed extracts on human tumour cell lines: Role of reactive oxygen species and glutathione. J Biosciences 2005; 30(2): 237-44.

[18] Sadik G, Islam R, Rahman MM, Khondkar P, Rashid MA, Sarker SD. Antimicrobial and cytotoxic constituents of Loranthus globosus. Fitoterapia 2003; 74(3): 308-11.

[19] Ordoñez AAL, Gomez JG, Vattuone MA, Isla MI. Antioxidant activities of Sechium edule (Jacq.) Swart extracts. Food Chem 2006; 97: 452-458.
[20] Sun JS, Tsuang YH, Chen IJ, Huang WC, Hang YS, Lu FJ. An ultra-weak chemiluminescence study on oxidative stress in rabbits following acute thermal injury. Burns 1998; 24(3): 225-31.

[21] Oyaizu M. Studies on products of browning reactionantioxidative activities of products of browning reaction prepared from glucosamine. Japanese J Nutr 1986; 44 (6): 307-315.

[22] Choi HY, Jhun EJ, Lim BO, Chung IM, Kyung SH, Park DK Application of flow injection-chemiluminescence to the study of radical scavenging activity in plants. Phytotherapy Res 2000; 14(4): 250-3.

[23] Garrat DC. The Quantitative analysis of drugs. London: Chapman and Hall Ltd.; 1964.

[24] Ellman GL, Courtney KD, Andres V, Featherstone RM. A new and rapid colorimetric determination of acetylcholinesterase activity. Biochemical Pharmaco 1961; 7(2): 88-95.

[25] Uddin MS, Mamun AA, Sarwar MS, Chaity NH, Haque A Akter N, Amran MS. Medicine that causes memory loss: Risk of neurocognitive disorders. Int Neuropsych Dis J 2016; 8(1): 1-18. http://dx.doi.org/10.9734/INDJ/2016/26317

[26] Nelson PT, Alafuzoff I, Bigio EH, et al. Correlation of Alzheimer disease neuropathologic changes with cognitive status: A review of the literature. J Neuro Exp Neur 2012; 71(5): 362-381.

[27] Mamun AA, Uddin MS, Wahid MF, Iqbal MA, Rahman MM. Neurodefensive effect of Olea europaea L. in alloxaninduced cognitive dysfunction and brain tissue oxidative stress in mice: Incredible natural nootropic. J Neurology Neurosci 2016; 7(S3): 1-9.

[28] Balmus IM, Ciobica A, Antioch I, Dobrin R, Timofte D. Oxidative Stress implications in the affective disorders: Main biomarkers, animal models relevance, genetic perspectives, and antioxidant approaches. Oxi Med Cellular Lon 2016; 2016: 1-25

[29] Grossberg GT. Cholinesterase inhibitors for the treatment of Alzheimer's disease: Getting on and staying on. Cur Ther Re, Cli Exp 2003; 64(4): 216-235.

[30] Murray AP, Faraoni MB, Castro MJ, Alza NP, Cavallaro V. Natural AChE Inhibitors from plants and their Contribution to Alzheimer's disease therapy. Current Neuropharma 2013; 11(4): 388-413.

[31] Oliveira RI, Guimarães Al, Paula A, Oliveira LA, Ribeiro A Lucio SS, et al. Phenolic quantification and antioxidant activity of Anaxagorea Dolichocarpa and Duguetia Chrysocarpa (Annonaceae). Int J Pharma Bio Sciences 2011; 3(4): 368-379.

[32] Bayard V, Chamorro F, Motta J, Hollenberg NK. Does flavanol intake influence mortality from nitric oxide-dependent processes? Ischemic heart disease, stroke, diabetes mellitus, and cancer in Panama. Int J Med Sci 2007; 4(1): 53.

[33] Gang DR. Biological activity of phytochemicals. New York: Springer; 2011.

[34] Feng $Y$, Wang X. Antioxidant therapies for Alzheimer's disease. Oxi Med Cel Lon 2012; 2012: 1-5.

[35] Alves-Amaral G, Pires-Oliveira M, Andrade-Lopes AL, Chiavegatti T, Godinho RO. Gender-related differences in circadian rhythm of rat plasma acetyl-and butyrylcholinesterase: Effects of sex hormone withdrawal. Chemico-Bio Int 2010; 186(1): 9-15.

[36] Vijayapandia P, Annabathina V, SivaNagaSrikanth B, Manjunath $\mathrm{V}$, Boggavarapu $\mathrm{P}$, RajendraPrasad $\mathrm{K}$, Kumarappan CT. In vitro anticholinergic and antihistaminic activities of Acorus calamus Linn. Leaves extracts. Afr J Trad, Com Alt Med 2013; 10(1): 95-101.

[37] Suganthy N, Pandian SK, Devi KP. Cholinesterase inhibitory effects of Rhizophora lamarckii, Avicennia officinalis, 
Sesuvium portulacastrum and Suaeda monica: Mangroves inhabiting an Indian coastal area (Vellar Estuary). J Enzyme Inhib Med Chem 2009; 24(3): 702-7.

[38] Singh S. Antioxidants as a preventive therapeutic option for age related neurodegenerative diseases. Therapeutic Tar Neu Dise 2015; 2: e592.

[39] Gourigari TR, Lepakshi BM, Kamsala RV. Evaluation of anticholinergic, antidiabetic and antioxidant activity of leaf extracts of Ochna Obtusata Dc using in vitro assays. Int J Pharm Pharmace Sci 2016; 8(6): 82-7.

[40] Kuate D, Etoundi BC, Soukontoua YB, Ngondi JL, Oben JE. Comparative study of the antioxidant, free radical scavenging activity and human LDL oxidation inhibition of three extracts from seeds of a Cameroonian spice, Xylopia parviflora (A.
Rich.) Benth. (Annonaceae). Int J Biomed Pharm Sci 2011; 5: 18-30.

[41] Mathew M, Subramanian S. In vitro screening for anticholinesterase and antioxidant activity of methanolic extracts of ayurvedic medicinal plants used for cognitive disorders. PLoS One 2014; 9(1): e86804.

[42] Uddin MS, Mamun AA, Iqbal MA, Islam A, Hossain MF, Khanum S, Rashid M. Analyzing nootropic effect of Phyllanthus reticulatus Poir. on cognitive functions, brain antioxidant enzymes and acetylcholinesterase activity against aluminium-induced Alzheimer's model in rats: Applicable for controlling the risk factors of Alzheimer's disease. Adv Alzheimer Dis 2016; 5(3): 87-102. http://dx.doi.org/10.4236/aad.2016.53007

Received on 27-03-2017

DOI: https://doi.org/10.6000/2292-2598.2017.05.02.3

(C) 2017 Rahman et al.; Licensee Lifescience Global.

This is an open access article licensed under the terms of the Creative Commons Attribution Non-Commercial License (http://creativecommons.org/licenses/by-nc/3.0/) which permits unrestricted, non-commercial use, distribution and reproduction in any medium, provided the work is properly cited. 